\title{
Impact of the 2012 Drought on Woody Vegetation Invading Alvar Grasslands in the Burnt Lands Alvar, Eastern Ontario
}

\author{
Paul M. CATLing
}

Environmental Health, Biodiversity, Saunders Building, Central Experimental Farm, Agriculture and Agri-Food Canada, Ottawa, Ontario K1A 0C6, Canada; email: Paul.Catling@agr.gc.ca

Catling, Paul M. 2014. Impact of the 2012 drought on woody vegetation invading alvar grasslands in the Burnt Lands Alvar, eastern Ontario. Canadian Field-Naturalist 128(3): 243-249.

Counts of dead and living trees in open alvar indicated that the 2012 drought had a significant impact on the Burnt Lands Alvar in eastern Ontario, with mortality of woody species ranging from $10 \%$ to $100 \%$ at open alvar sites. The maximum age of dead trees suggested that the most recent drought of similar impact occurred more than 35 years ago, possibly in 1974. Some of the killed junipers were 87-90 years old. All dry periods indicated on a summer rainfall diagram may not be severe enough to kill woody vegetation, but a drought causing an average $50 \%$ kill of woody vegetation in open alvar may have occurred at least once every 30 years over the past century. Consequently the encroachment of woody species into alvar grassland appears not to be a threat to this habitat. Open alvar could have existed on the landscape as isolated occurrences since early postglacial times, if the climate fluctuated in the distant past as it has recently. With evidence for drought in a fluctuating climate to maintain the disjunct occurrences of midwestern plant and animal species, these occurrences may be considered as reliable indicators of a more continuous distribution of such species more than 10000 years ago.

Key Words: alvar; Great Lakes region; eastern Ontario; drought; woody vegetation; succession; Common Juniper; Juniperus communis; White Spruce; Picea glauca; Eastern White Pine; Pinus strobus; Eastern White Cedar; Thuja occidentalis

\section{Introduction}

Alvar grasslands are naturally open areas of thin soil over flat limestone or marble rock with a more-or-less sparse grass-dominated vegetation with trees absent (Catling and Brownell 1995). Three kinds of predominant alvar grassland are considered to be globally imperiled, meaning that they are "at high risk of extinction or elimination due to restricted range, few populations or occurrences, steep declines, severe threats, or other factors" (Natureserve 2014). Alvar grasslands also contain a diversity of plants and animals, some of which have been evaluated as at risk or susceptible to extirpation (Catling et al. 2014), reflecting the fact that these habitats are subject to a variety of threats. Alvar habitats are important with regard to climate change studies, and the grasslands, in particular, are believed to be the only existing analogues of the Picea parkland that existed in front of the Wisconsin glacier for hundreds of thousands of years (Webb 1987). Alvars also provide in situ protection for native crop relatives and major recreational opportunities (Catling et al. 2014).

The survival of alvar grassland in the northern Great Lakes region since the early postglacial period (e.g., Catling and Brownell 1995; Hamilton and Whitcomb 2010) was likely the result of resistance to succession to woodland as a consequence of fire removing trees and shrubs, periodic drought, and a seasonal cycle of drought and flooding (Catling and Brownell 1995; Jones and Reschke 2005). The effects of fire at a number of sites in the Great Lakes region have been reported to range from the creation and maintenance of grasslands to no effect (e.g., Catling and Brownell 1998; Jones and Reschke 2005; Catling 2009), and it has been conclud- ed that, in some situations, fire is "not the primary factor in maintaining open condition" (Jones and Reschke 2005). The seasonal cycle of spring flooding and late summer drought can be seen on an annual basis, but only Stephenson and Herendeen (1986), working at Maxton Plains in northern Michigan, have documented the impact of periodic drought on alvar grassland over a longer term. An opportunity to add to their observations arose with the drought of 2012 when woody vegetation declined on the northern part of the Burnt Lands Alvar in the Ottawa Valley of eastern Ontario. At the end of the summer of 2012, leaves on many of the predominant conifers had turned brown, and much of the brown leaf material and dead branches were evident on the trees and Juniper shrubs (personal observation).

In this article, I explore the idea that drought had a significant effect in restricting woody growth on the Burnt Lands Alvar through analysis of data on mortality of woody plants. In general, this work is designed to improve understanding of the derivation and future of alvar habitats by elucidating the factors that control species composition and, specifically, those that relate to the threat of forest encroachment.

\section{Study Area}

The Burnt Lands Alvar, $4 \mathrm{~km}$ northeast of Almonte, Mississippi Mills, Ontario, at approximately 45.2698, -76.1942 is a $15-\mathrm{km}^{2}$ area of provincially significant flora and fauna (Brunton 1986*), much of which is within Burnt Lands Provincial Park. The grasslands here are dominated by perennial Prairie Dropseed (Sporobolus heterolepis [A. Gray] A. Gray) and annual Sheathed Dropseed (Sporobolus vaginiflorus [Torrey ex. A. Gray] 


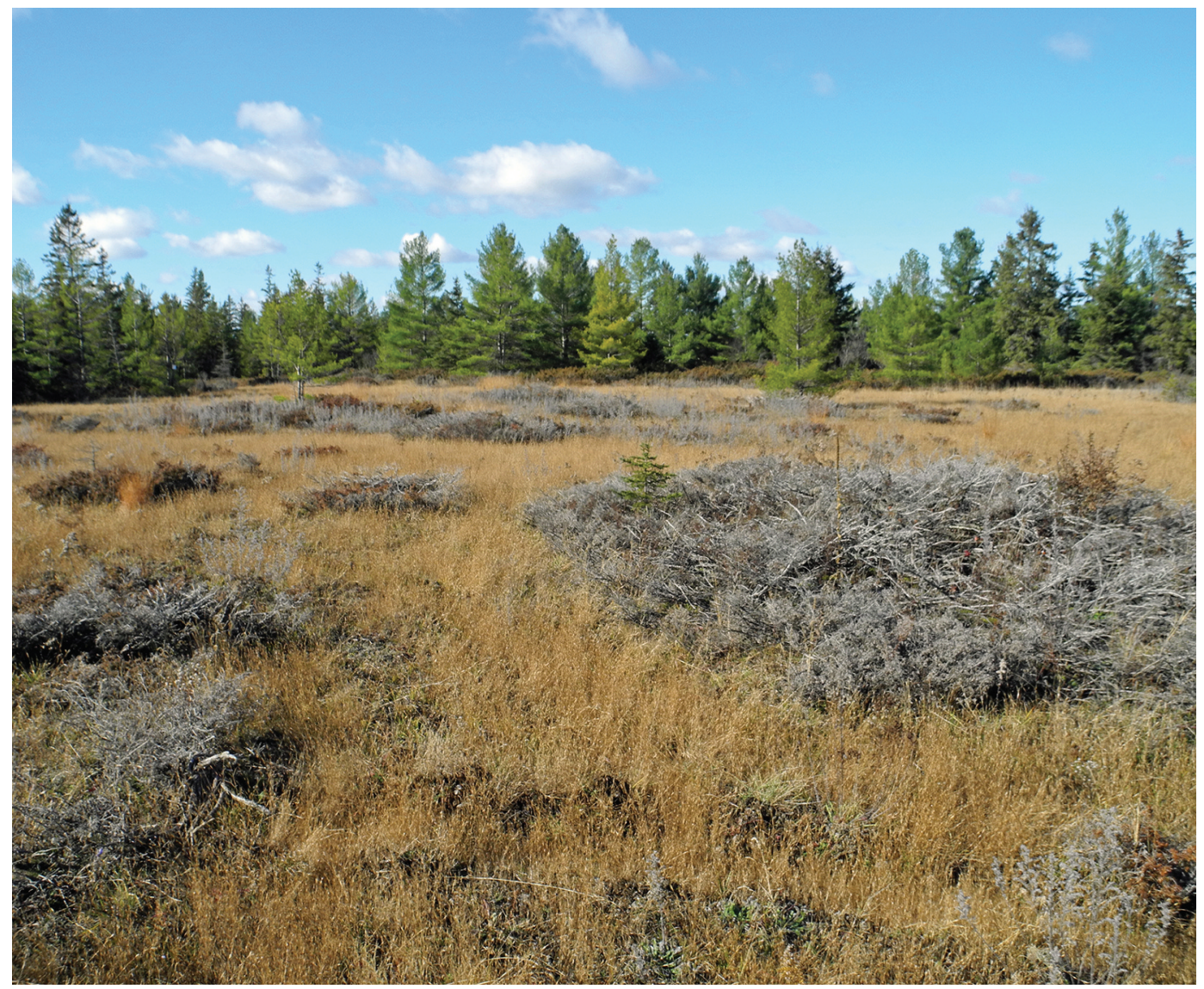

Figure 1. Dead Common Juniper (Juniperus communis) in alvar grassland at the north end of the Burnt Lands Alvar, Eastern Ontario. The shrubs were killed by the extreme drought in 2012. Photo: P. M. Catling, September 2013.

Alph. Wood var. vaginiflorus) with numerous other prominent species characteristic of alvars also present, including Crawe's Sedge (Carex crawei Dewey), Small Skullcap (Scutellaria parvula Michaux), False Pennyroyal (Trichostema brachiatum L.), and Balsam Groundsel (Packera paupercula [Michaux Á. Löve \& D. Löve). Other species locally common are Common Self-heal (Prunella vulgaris L.), Oxeye Daisy (Leucanthemum vulgare Lamarck), Tall Hawkweed (Hieracium piloselloides Vill.) and Common Viper's Bugloss (Echium vulgare L.). The grasslands are surrounded by forest dominated by Eastern White Cedar (Thuja occidentalis L.) with Common Juniper (Juniperus communis L.), White Pine (Pinus strobus L.), and White Spruce (Picea glauca [Moench] Voss). These woody species are also present as individuals within the grassland. The earlier established woody species provide shade that reduces water loss for later colonizers resulting in patches of woody plants. Through this process of nucleation, woodland begins to replace open alvar.

\section{Methods}

To test the hypothesis that the 2012 drought had a significant impact on woody species, the following data were gathered in late September 2013, one year after the drought and at a time when the drought impact was conspicuous with persisting dead branches and branches retaining brown leaves (Figures 1 and 2).

\section{Age of woody vegetation killed}

The age of some of the larger woody plants killed was determined by counting growth rings of cut dead trees with a stereo microscope. Resolution of growth rings was improved through the application of linseed oil to the cut surfaces. Seven Eastern White Cedars and three White Spruces were cut at breast height, and diameter at breast height (dbh) was measured. Five years was added to the growth ring estimates to account for the time required to reach breast height and make estimates of age more accurate. The ages of three White Pines were estimated by counting spaces between branches on the trunk. Three Common Junipers were cut at the stem base and growth rings were counted. 


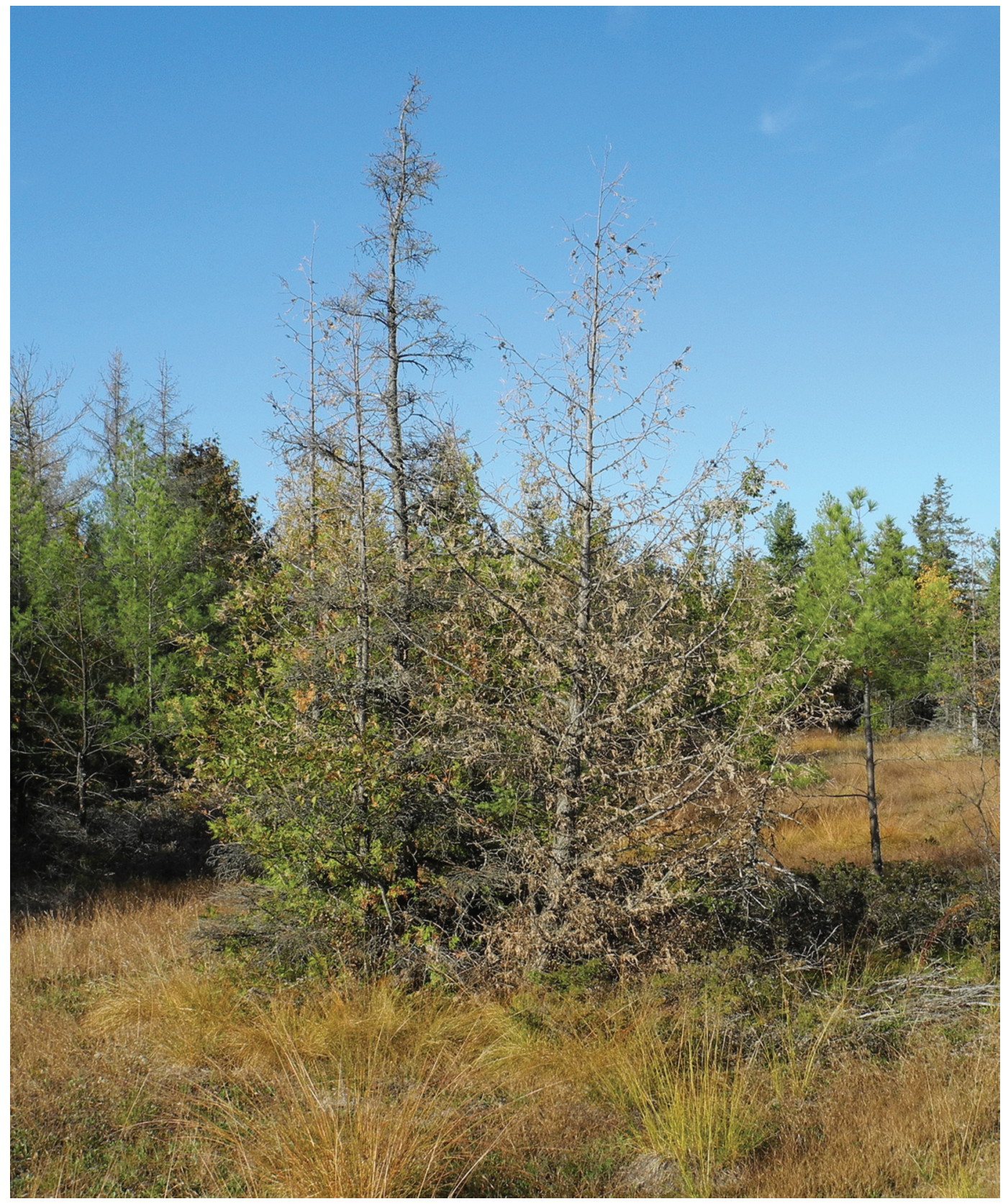

Figure 2. Dead Eastern White Cedar (Thuja occidentalis, front right) and dead White Spruce (Picea glauca, centre) in a nucleation patch with some living cedar (left) and half dead Common Juniper (Juniperus communis, bottom left). The dead cedar and spruce were approximately 30 years old as indicated by a count of growth rings. These trees were killed in 2012, when $60 \%$ of the trees in nucleation patches in the Burnt Lands Alvar, Eastern Ontario, died apparently due to extreme drought. Photo: P. M. Catling, September 2013. 
Decline of woody vegetation along a limestone pavement crack

Based on the amount of living material compared with dead leaves and leafless branches, trees and shrubs were classified as dead, half dead, or alive and mapped along two, 25-m long cracks in the flat bedrock (limestone pavement) to provide a visual indication of the impact of the drought in an area of heavy damage. The area examined was rectangular $(20 \mathrm{~m} \times 25 \mathrm{~m})$. Dbh for trees and maximum diameter of branch spread (i.e., of the patch) for juniper shrubs were recorded and indicated on the diagram (Figure 3 ). The dbh and shrub diameters were also used to calculate percentage decline (total dbh or patch size of dead material divided by total dbh or patch size times 100).

\section{Juniper decline in open grassland}

The maximum diameter of more or less circular patches of juniper was recorded in an open rectangular area $50 \mathrm{~m} \times 100 \mathrm{~m}\left(5000 \mathrm{~m}^{2}\right)$ and the extent to which patches had died, in terms of percentage of lost surface area, was estimated to within 5\%.

General decline of woody vegetation in open grassland

At three sites separated by $0.5-1 \mathrm{~km}$, the status of all trees and shrubs in alvar grassland was recorded as dead, half dead, or alive (see above), and dbh for trees and maximum diameter for juniper shrubs was recorded. For each of the tree species and for each status category, the number of individuals, the dbh range and total of all dbh measurements were noted (Table 1). The sizes of areas surveyed are indicated in Table 1. From the data for dead tissue (total dbh for dead trees $+1 / 2 \mathrm{dbh}$ for half dead trees), a percentage decline for all trees was calculated by dividing by the total dbh and multiplying by 100 . A percentage decline for juniper shrubs was calculated by dividing loss of surface area by total surface area of patches times 100 .

\section{Documentation of the drought of 2012}

Total rainfall for June, July, and August was used to identify drought years from 1890 to present. Rainfall is only an approximation of drought because the evenness of the pattern of rainfall for the period is not considered, nor is localized convectional rain, which may differ between a recording station and an area under consideration. The amount of heat, which increases water loss by evapotranspiration, is also an important factor that is not considered here. Although it is not an entirely reliable indication of drought, low total rainfall is highly correlated with severe drought impact and is, thus, helpful in determining drought occurrences if these limitations are taken into account.

Historical Environment Canada (2014) weather data for the closest stations were used. Because the record for the nearest town, Almonte, is incomplete, the record for Ottawa $(45.38333,-75.71666), 40 \mathrm{~km}$ east by southeast of the study site, was used for the period 1890-2006. For 2007-2013, the potentially more accurate data from the nearby village of Appleton (45.18683,

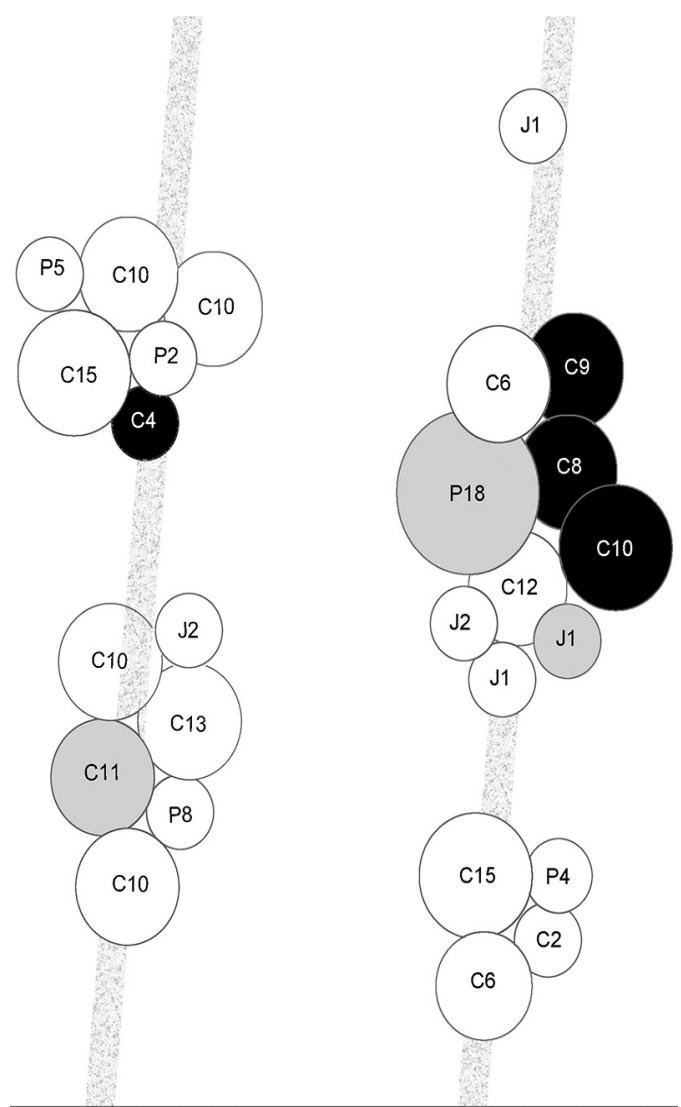

FIGURE 3. Diagram showing status of woody vegetation along two pavement cracks (stippled) at the north end of the Burnt Lands Alvar, Eastern Ontario. The diagram is based on a field sketch of a rectangular area $20 \times$ $25 \mathrm{~m}$ and is drawn approximately to scale. Circles are trees and shrubs, where $\mathrm{C}=$ Eastern White Cedar (Thuja occidentalis), $\mathrm{P}=$ White Pine (Pinus strobus), $\mathrm{J}=$ Common Juniper (Juniperus communis) and white $=$ dead, grey $=$ half-dead, and black $=$ alive . The numbers for cedar and pine are diameter of the trunk at breast height in $\mathrm{cm}$; for junipers they are diameter of the whole shrub (m).

$-76.10768), 12 \mathrm{~km}$ south by southeast of the study site, were used.

\section{Results}

\section{Age of woody vegetation killed}

The interpretation of growth rings was difficult in some areas and resulted in a range of values. Harvested Eastern White Cedar was 34-40 years old with dbh ranging from 15 to $17 \mathrm{~cm}$. White Spruce was of similar age and diameter, while White Pine ranged from 35 to 50 years old. Most dead Common Juniper shrubs were older than the trees: 33-90 years old and 3-13 cm dbh. 
TABLE 1. Measurements of dead, half-dead and living Eastern White Cedar (Thuja occidentalis), White Spruce (Picea glauca), White Pine (Pinus strobus), and Common Juniper (Juniperus communis) at three open alvar grassland sites on the Burnt Lands Alvar, Eastern Ontario.

\begin{tabular}{|c|c|c|c|c|c|c|c|c|c|}
\hline \multirow[b]{2}{*}{ Species and measures } & \multicolumn{3}{|c|}{ Site $1(45 \times 80 \mathrm{~m})$} & \multicolumn{3}{|c|}{ Site $2(25 \times 55 \mathrm{~m})$} & \multicolumn{3}{|c|}{ Site $3(28 \times 42 \mathrm{~m})$} \\
\hline & Dead & $\begin{array}{l}\text { Half- } \\
\text { dead }\end{array}$ & Alive & Dead & $\begin{array}{l}\text { Half- } \\
\text { dead }\end{array}$ & Alive & Dead & $\begin{array}{c}\text { Half- } \\
\text { dead }\end{array}$ & Alive \\
\hline \multicolumn{10}{|l|}{ Eastern White Cedar } \\
\hline Number & 16 & 2 & 10 & 19 & 2 & 8 & 12 & 1 & 19 \\
\hline Dbh range $(\mathrm{cm})$ & $1-20$ & 4 & $1-9.5$ & $2-16$ & $5-14$ & $3-14$ & $1-18$ & 7 & $1.5-16$ \\
\hline Total dbh $(\mathrm{cm})$ & 96.7 & 8 & 33.3 & 176 & 19 & 67 & 84 & 7 & 111 \\
\hline \multicolumn{10}{|l|}{ White Spruce } \\
\hline Number & 2 & - & 4 & - & - & - & 6 & - & - \\
\hline Dbh range $(\mathrm{cm})$ & $5-6$ & - & $3-12$ & - & - & - & $2-10$ & - & - \\
\hline Total dbh $(\mathrm{cm})$ & 11 & - & 22 & - & - & - & 20 & - & - \\
\hline \multicolumn{10}{|l|}{ White Pine } \\
\hline Number & 2 & - & - & - & - & 2 & 3 & 1 & - \\
\hline Dbh range $(\mathrm{cm})$ & $2.3-2.4$ & - & - & - & - & $20-28$ & $12-15$ & 7 & - \\
\hline Total dbh $(\mathrm{cm})$ & 4.7 & - & - & - & - & 48 & 39 & 7 & - \\
\hline \multicolumn{10}{|l|}{ Common Juniper } \\
\hline Number & 8 & 1 & 5 & 1 & 3 & 3 & 1 & 3 & 1 \\
\hline Patch diameter $(\mathrm{m})$ & $0.8-2.5$ & 0.6 & $0.3-1.8$ & 2 & $3-5$ & $2-4$ & 1 & $1-3$ & 4 \\
\hline Total of all patches $(\mathrm{m})$ & 10.9 & 0.6 & 3.9 & 2 & 12 & 9.5 & 1 & 5 & 4 \\
\hline \multicolumn{10}{|l|}{ All trees } \\
\hline Total dbh (cm) & 175.7 & & & 310.0 & & & 268.0 & & \\
\hline$\%$ decline & 66.3 & & & 59.8 & & & 56.0 & & \\
\hline \multicolumn{10}{|l|}{ Common Juniper } \\
\hline Total of all patches (m) & 15.4 & & & 23.5 & & & 10.0 & & \\
\hline$\%$ decline & 72.7 & & & 34.0 & & & 35.0 & & \\
\hline
\end{tabular}

Decline of woody vegetation along a pavement crack Most of the trees and shrubs in nucleation patches along a pavement crack were killed (Figure 3 ). The larger dead cedars (those about $15 \mathrm{~cm} \mathrm{dbh}$ ) in these patches were likely over 30 years old based on $\mathrm{dbh}$ of the few trees of definitely known age. The overall decline of trees in these pavement cracks was $80 \%$ and that of junipers was $93 \%$.

\section{Juniper decline in open grassland}

Fifty-eight more-or-less circular patches of Common Juniper, 0.5-1 $\mathrm{m}$ in diameter occurred in the selected area. The majority of these shrubs were 35-45 years old based on basal stem diameters of a few trees of known age, and larger patches were composed of more than one plant. In 2012, 20 of the plants had died and many others had lost much of their foliage (Figure 1). The total area of living Common Juniper observed here at the start of 2012 had been approximately $274 \mathrm{~m}^{2}$ and this had declined to $88 \mathrm{~m}^{2}$ by the end of 2012 , representing a $68 \%$ reduction. This area included shrubs up to 90 years old.

General decline of woody vegetation in open grassland

The overall decline of trees at three sites ranged from $56 \%$ to $66 \%$ and decline of junipers ranged from $35 \%$ to $73 \%$. Thus over half of the woody vegetation in the openings was killed (Figure 2). Some of the trees at all three sites were over 35 years old, but all age classes and all three tree species were affected by the drought (Table 1).

\section{Documentation of the drought of 2012}

Since 1890 , the average annual summer precipitation in the Ottawa area has been $255 \mathrm{~mm}$. Based on this average and the pattern, a plot for this period (Figure 4) shows that unusually dry years (less than $160 \mathrm{~mm}$ of rain in June-August), approximately equivalent to the 2012 drought, have occurred on average

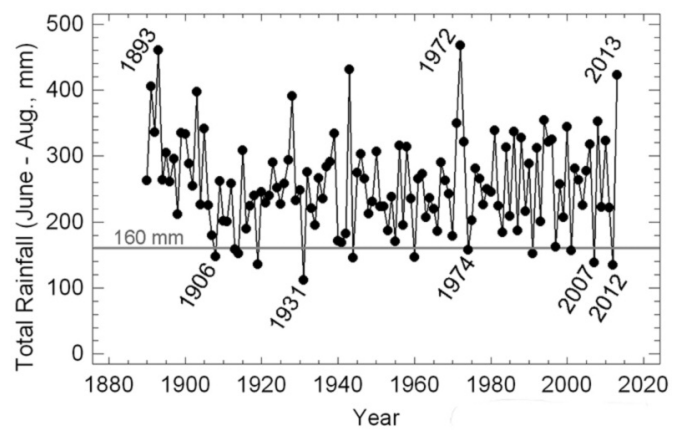

FIGURE 4. Summer rainfall (mm) from 1890 to 2013 near the Burnt Lands Alvar, Eastern Ontario, based on records of Environment Canada (2014). 
every 8 years. The period from 1890 to 1906 was evidently the longest drought-free period on record. The 2012 drought was the second-most extreme in terms of limited rainfall $(134 \mathrm{~mm})$, the most extreme being the drought of $1931(112 \mathrm{~mm})$.

Unusually wet years (over $380 \mathrm{~mm}$ of rain in JuneAugust) have occurred less frequently (Figure 4) than unusually dry years, with an average of 20 years between. Before 2013 (432 mm), the last unusually wet year occurred in $1972(468 \mathrm{~mm})$ and was the wettest on record.

\section{Discussion}

The 2012 drought had an impact on the Burnt Lands Alvar that was very similar to that reported for Maxton Plains (Stephenson and Herendeen 1986), where woody species mortality ranged from $10 \%$ to $100 \%$ at open alvar sites. The wide variation at Maxton Plains and Burnt Lands Alvar may have been based on differences in surface water flow, making some sites more susceptible to woody plant mortality than others.

The variation in the age of dead trees on Burnt Lands Alvar may be a consequence of random differences in times of establishment. Assuming that the same dry sites are susceptible to consecutive droughts, and based on the age range of 34-50 years of the larger dead trees, the last droughts as severe as that of 2012 occurred 52 years ago in 1960 and 38 years ago in 1974. However, some of the killed junipers were 87-90 years old and had survived droughts for almost 100 years. Although the wet years have allowed woody invasions, the higher frequency of dry years, some severe, has prevented encroachment of woody plants into grasslands and other open areas.

The drought of 2007 did not have as severe an impact on woody vegetation as that of 2012 (personal observation) despite similarly low overall rainfall (Figure 4). Possibly different rainfall patterns, less local rain, and higher heat contributed to the much greater severity in 2012. A drop to a critical level of dryness may also have played a role in 2012. Although not all dry periods indicated on the total rainfall diagram were severe enough to kill woody vegetation, those potentially capable of doing so have occurred with a high enough frequency that a drought averaging a 50\% kill of woody vegetation in open alvar may have occurred once every 30 years over the past century. As this may be sufficient to maintain open alvar in many areas, it supports the conclusion of Stephenson and Herendeen (1986) that woody species encroachment into alvar grassland is not a threat to open alvar habitat. Studies of drought effects on some Scandinavian alvars, such as Stora Alvaret on the Swedish Island of Öland, have also documented a decline of juniper as a result of drought (Rosen 1984), although these alvars are often thought to have been largely created and maintained by livestock grazing (Znamenskiy et al. 2006).
By preventing encroachment of woody plants, periodic drought may provide a mechanism for the longterm persistence of species in alvars that are considered remnants of more continuous distributions in early postglacial landscapes. These occurrences of early postglacial and midwestern species assemblages, including, for example, the occurrence of the flightless leafhopper associated with the community-dominant Prairie Dropseed grass (Hamilton and Whitcomb 2010), now have a better supported theory to explain their isolation.

Although fire may have more impact on the edges of open alvar and in the creation of open alvar from alvar woodland (Catling 2009), or may vary in impact from one alvar to another (Jones and Reschke 2005), drought may prevent succession to forest on parts of open alvar and on alvar pavements not subject to fire. Drought may also promote fire by creating drier conditions and by increasing fuel. Consequently these processes may have a complementary effect in the maintenance of open conditions on alvars, but drought alone can have substantial impact.

\section{Documents Cited (marked * in text)}

Brunton, D. F. 1986. A life science inventory of the Burnt Lands. Ontario Ministry of Natural Resources, Carleton Place, Ontario, Canada. 118 pages +3 maps.

\section{Literature Cited}

Catling, P. M. 2009. Vascular plant diversity in burned and unburned alvar woodland: more evidence of the importance of disturbance to biodiversity and conservation. Canadian Field-Naturalist 123(3): 240-245.

Catling, P. M., and V. R. Brownell. 1995. A review of the alvars of the Great Lakes Region: Distribution, floristic composition, biogeography and protection. Canadian Field-Naturalist 109: 143-171.

Catling, P. M., and V. R. Brownell. 1998. Importance of fire in alvar ecosystems - evidence from the Burnt Lands, eastern Ontario. Canadian Field-Naturalist 112(4): 661667.

Catling, P. K.. P. M. Catling, J. Cayouette, and M. J. Oldham. 2014. Canadian Alvars and Limestone Barrens: Areas of "Special Conservation Concern" for plants? Canadian Botanical Association Bulletin. In press.

Environment Canada. 2014. Accessing the data. Environment Canada, Fredericton, New Brunswick, Canada. Accessed 20 Nov, 2013. http://climate.weather.gc.ca/.

Hamilton, K. G. A., and R. F. Whitcomb. 2010. Leafhoppers (Homoptera: Cicadellidae): a major family adapted to grassland habitats. Pages 169-197 in Arthropods of Canadian Grasslands. Volume 1: Ecology and Interactions in Grassland Habitats. Edited by J. D. Shorthouse and K. D. Floate, Biological Survey of Canada.

Jones, J., and C. Reschke. 2005. The role of fire in Great Lakes Alvar Landscapes. Michigan Botanist 44: 13-27.

NatureServe Explorer. 2014. NatureServe Conservation Status. NatureServe, Arlington, Virginia, USA. Accessed February 2014. http://explorer.natureserve.org/ranking.htm.

Rosen, E. 1984. Some short-term changes in the dynamics of limestone grassland of South Oland, Sweden. Acta Uni- 
versitatis Upsaliensis Nova Acta Regiae Societatis Scientiarum Upsaliensis Series V C. 3: 189-205.

Stephenson, S. N., and P. S. Herendeen. 1986. Short-term drought effects on the alvar communities of Drummond Island, Michigan. Michigan Botanist 25: 16-27.

Webb, T. 1987. The appearance and disappearance of major vegetational assemblages: long term vegetational dynamics in eastern North America. Vegetatio 69: 177-187.
Znamenskiy, S., Helm, A. and M. Partel. 2006. Threatened alvar grasslands in NW Russia and their relationships to alvars in Estonia. Biodiversity and Conservation 15: 17971809.

Received 6 January 2014

Accepted 14 February 2014 